PROBLEMISTIC SEARCH AND INTERNATIONAL ENTREPRENEURSHIP *

\author{
Karl Wennberg ** \\ Center for Entrepreneurship and Business Creation \\ Stockholm School of Economics \\ P.O. Box 6501 \\ SE-113 83 Stockholm \\ SWEDEN \\ Phone: +46-8-7369341 \\ Fax: +46-8-318186 \\ karl.wennberg@hhs.se \\ Carin Holmquist \\ Center for Entrepreneurship and Business Creation \\ Stockholm School of Economics \\ P.O. Box 6501 \\ SE-113 83 Stockholm \\ SWEDEN \\ Phone: $+46-8-7369355$ \\ Fax: $+46-8-318186$ \\ carin.holmquist@hhs.se
}

* The data used in this study owes an intellectual debt to the associated INTERSTRATOS research groups, composed of J. Hanns Pichler, Erwin Frölich and Peter Voithofer (Austria), Rik Donckels and Ria Arts (Belgium), Graham Hall (U.K.), Antti Haahti and Petri Ahokangas (Finland), Koos van Dijken and Harold Gankema (The Netherlands), Per-Anders Havnes, Arild Saether and Johanne Sletten (Norway), Håkan Boter and Carin Holmquist (Sweden), and Hans Pleitner and Margrit Habersaat (Switzerland). We are indebted to Erkko Autio, Sara Mélen, Frédéric Delmar, Jerker Denrell, Stefan Jonsson, Sune Karlsson, seminar participants at Stockholm School of Economics, Jönköping International Business School, Copenhagen Business School, and especially to Siri Terjesen, Christian Geissler Asmussen and Henrich Greve for help and suggestions. The usual caveats apply.

** Corresponding author. 


\title{
PROBLEMISTIC SEARCH AND INTERNATIONAL ENTREPRENEURSHIP
}

\begin{abstract}
This paper explains the internationalization process of small firms using the theory of performance relative to aspiration levels. The study complements prior theory by explaining why and how small firms are triggered to engage in internationalization despite not reaching maturity in their home market. We outline a model where firms' internationalization is triggered by problemistic search, following periods of below-aspiration performance. The model is tested on 860 Swedish firms followed during an economic downturn. Results indicate that internationalization activities follow a boundedly rational process characterized by search behavior which is triggered by performance feedback. The study complements prior theories of internationalization and offers a first empirical demonstration of the viability of aspiration-level performance theory in international entrepreneurship research.
\end{abstract}

\section{Introduction}

Do firms engage in international business primarily in response to saturation in their home market, or can weakening performance be an equally strong drive of internationalization? Established conceptual frameworks describe firm internationalization as a behavioral process where risk-avoiding firms' learnings from prior internationalization attempts spur expansion into foreign markets, beginning first in markets of close geographic proximity and then moving into markets that are characterized by a psychic proximity (Bilkey, 1978; Johanson and Vahlne, 1977). These frameworks successfully describe the general development of firms' internationalization activities and the eventual transformation into multinational corporations, but do not explain why or how internationalization processes are initiated in the first place (Andersen, 1993). Furthermore, the predictions of existing behavioral internationalization theory run counter to accumulating evidence indicating that small entrepreneurial firms that go international often follow very different modes, for example by entering directly into distant 
markets, and more swiftly adjusting their actions to environmental feedback (Bingham and Eisenhardt, 2005; Madsen and Servais, 1997; Oviatt and McDougall, 1994).

This paper develops and tests aspiration-level performance theory as a driver of new firm's initial and subsequent progress of new firms' internationalization activities. The theory of aspiration-level performance, or 'performance feedback theory', builds on Cyert and March's (1963) and Simon's (1955) the Behavioral Theory of the Firm (BTF). Although the early internationalization frameworks are behaviorally oriented, most empirical internationalization research either disregards the BTF or simply alludes to it, without formally integrating the two theoretical components of decision-making: problemistic search and aspiration levels (Madsen, 2005). Our behavioral perspective on small firm's internationalization thus follows a general call for a clarification of the domain of international entrepreneurship and its relevant theories (McDougall \& Oviatt, 2000; Acs, Dana, \& Jones, 2003).

We argue that international entrepreneurship theory could benefit from integrating the key theoretical components of the BTF. Much empirical work on internationalization, particularly that of new entrepreneurial firms, focuses on firms' and firm founders' traits and characteristics (cf. Autio, Sapienza \& Almeida, 2000; McDougall, Shane and Oviatt, 1994). This static approach stands in contrast to the common descriptions of new entrepreneurial firms as strategically nimble and able to quickly adapt to new market situations (cf. Schonhoven, Eisenhardt and Lyman 1990). We therefore believe that the BTF is suitable for such cases where deteriorating performance is a trigger for internationalization and in this respect offer an alternative way of understanding internationalization processes in small entrepreneurial firms. Using the BTF as a framework for small firms' internationalization activities, we draw upon advances in organization and strategy research that has built upon the BTF (cf. Baum et al., 2005; Greve; 2003a; Audia and Greve, 2006). This growing body of research, generally referred to as 'performance feedback 
theory' (Greve, 2003b), have investigated how performance relative to a specific aspiration level affects the rate and direction of organizational change, but internationalization has hitherto never been included in such models of change. While the original model was presented by Cyert and March (1963) in a context of established firms, the behavioral aspects of decision-making and strategy are strongly present in new and small firms. For example, feedback loops and search for new market opportunities are especially evident in new entrepreneurial firms (Bingham and Eisenhardt, 2005; Cooper, Folta and Woo, 1995). We use the BTF to outline a conceptual model that highlights the role of performance relative to firms' heterogeneous aspiration levels in triggering problemistic search for international expansion.

Testing a behavioral model of this type necessitates data on longitudinal measures of performance and behavior, and internationalization measures. We use a dataset that tracks a stratified random sample of 860 Swedish small- and medium-sized enterprises (SMEs) during the period 1991 to 1995. Exploratory studies on a subset of four firms indicated a general pattern that internationalization was not a process separate from other processes within the firm. Three of the firms we interviewed indicated that a strategy of internationalization could be triggered as well as delayed, given changes in performance. Two firms indicated that decreasing margins in their home market was a key trigger in their decisions to go international. Using these tentative ideas to guide our theorizing, we derive hypotheses from our conceptual model where performance below aspiration levels induce problemistic search for ways to increase exports, and where search increase the possibility of finding new ways to achieve increased exports. Our empirical test involves two steps: First, we estimate logit models to determine the effects on search behavior by performance below or above a firm's aspiration level. Subsequently, we investigate the joint effect of aspiration-level performance and search on internationalization attempts by fitting a series of negative binomial models. This study offers contributions to international 
entrepreneurship theory by highlighting the possibility of strengthening the expanding framework of international entrepreneurship theory with the behavioral theory of how performance relative to aspiration induces problemistic search for new opportunities. The theoretical model complements established theories' focus on incremental development in firms' internationalization processes by highlighting aspiration-level performance as a trigger for initiating internationalization attempts.

\section{Theoretical Development}

\section{International Entrepreneurship}

Recent internationalization research describes international new ventures (Oviatt and McDougall, 1994) or Born Globals (Andersson, 2000; Madsen and Servais, 1997) as distinct from traditional models of internationalization of large and established firms, which initiate internationalization only after reaching sufficient certain size in their home market (for a more thorough development of this argument, see e.g. Oviatt and McDougall, 1994; 1999). Zahra and George (2002) argue that the discussions on new venture internationalization constitute an emerging field of "international entrepreneurship," a field positioned at the intersection of two research paths: internationalization theory and entrepreneurship theory. Being an emerging field, no overarching theory has yet established its influence by describing the role of entrepreneurship in internationalization processes (Jones \& Coviello, 2005). Researchers therefore adopt existing theoretical frameworks such as the resource-based view (Westhead, Wright and Ucbasaran, 2001) or stage models common in traditional internationalization theory (Johansson and Vahlne, 2003). In this paper we draw upon the BTF which, to the best of our knowledge, has never been applied in the empirical setting of international entrepreneurship. 
Madsen (2005) investigates the treatment of the BTF in the major strands of internationalization theory, finding that while conceptual models of firm internationalization discuss the theory, most applied empirical work essentially ignores the BTF. In cases where arguments from the BTF are used, such as the Uppsala model (Johanson \& Vahlne, 1977), the focus is limited to firms' risk-aversion as a source of incremental steps in the internationalization process (Madsen, 2005). Leonidou and Katsikeas (1996) argue that both the Uppsala model and the various relatedness models by e.g. Bilkey (1978) are static models that do not explain or predict how or when internationalization processes are initiated, rather these models focus on what propels a firm's already ongoing internationalization activities. Melin (1992) pointed out that all stage models, such as the Uppsala model or the relatedness model by Bilkey are inadequate in that they predict a specific sequence of activities, and as such cannot explain how firms will respond to environmental factors that force them to deviate from this sequence. A possible exception is the work by Loustarinen (1979) that highlights that the combination of a perception of problems on the domestic market threats and the presence of foreign business opportunities can be a powerful trigger for internationalization, but that domestic problems are often a stronger trigger for active search efforts.

Also Oviatt and McDougall (1999) criticize these predominant internationalization models for being static models unable to explain or predict the dynamic patterns that firms' internationalization processes often take. A consequence of these arguments are that existing internationalization models that are behaviorally oriented, such as the Uppsala model, are incomplete in that they suffer from underspecification of antecedents and important causal factors in internationalization processes.

Also in empirical work on the internationalization of small entrepreneurial firms, little consideration has been given to the time-based aspects of behaviors and processes. In a review of 
the sixteen empirical studies of small firms' internationalization published in major journal outlets between 1992 and 1998, Coviello and McAuley (1999) identify only three studies that measured variables or followed firms over time, despite the strong common theoretical focus on small entrepreneurial firms' development and internationalization as processes (for similar arguments see also Leonidou and Katsikeas, 1996). Instead, extant studies of small firms' internationalization concentrate on how stable characteristics of the firm or of its managerentrepreneur affect its internationalization, for instance how the age, knowledge intensity, and imitability of the firm affects its growth in international markets (Autio et al., 2000) or how individual manager-entrepreneurs' experience or strategies influence firm internationalization (McDougall et al., 1994). These studies have helped us to understand the distinction between small and large firms internationalization. However, there is a dearth of studies focusing on the actual strategies and decision-making of small entrepreneurial firms that go international, Further, empirical studies frequently focus on the individual manager's impact on internationalization decisions but few studies consider how involvement in - and feedback from - ongoing activities affects the decision-making behavior of managers viz. engagement in international business. In this paper we consequently relate activities and strategic decisions, rather than traits and characteristics, to internationalization processes.

\section{Internationalization and aspiration-level performance}

By internationalization we mean a process in which firms develop increasing involvement in operations outside of their country of origin (Welch and Loustarinen, 1988). Why is performance feedback theory level relevant for internationalization? The theory derives its framework from the BTF by conceptualizing organizational decision-makers as boundedly rational agents who base their decisions on performance relative to earlier aspirations (Cyert and 
March, 1963). Simon (1955) first introduced the aspiration-level concept in connection to his idea that decision-makers interpret outcomes as either satisfactory or unsatisfactory, with an aspiration level constituting the boundary between the two (Augier and March, 2003). Cyert and March's seminal work formulated these arguments into testable mathematical propositions. These studies have established that the basic propositions of the BTF hold in a large variety of settings. However, the theory has not yet been tested in an internationalization setting.

Most behavioral research suggests that if performance falls below the aspiration level it will draw the organization's attention to the need for improving operations, stimulating risktaking, and search for and experimentation with new activities (Cyert and March 1963). The predictions presented by the BTF and the characterization of individual managers as boundedly rational have also been substantiated by the large body of psychological studies of framing effects, for example those summarized in Kahneman and Tversky's (1979) prospect theory. This is important, given the smaller organizational structure and frequent dependence on one or a small number of key persons in small entrepreneurial firms.

Entrepreneurship theory indicates that bounded rationality is particularly important for new and small firms as entrepreneurs are sensitive to performance relative to some reference point (Busenitz and Barney, 1997; Gimeno, Folta, Cooper and Woo, 1997). When engaging in international business, outcomes are often very uncertain, even more so than for domestic business. Research on individual entrepreneurs' cognition has shown that perception of or uncertainty can prevent a firm from internationalizing at all but such perception is also closely associated with the tolerance for ambiguity among entrepreneurs (Acedo \& Jones, 2007). Hence, uncertainty is one of the reasons why internationalization processes differ so much between firms (Andersson, 2000; Loustarinen, 1979), which provides a clue to the problems of international entrepreneurship research in fitting the available empirical evidence to an overarching theoretical 
framework. Some firms engage in internationalization due to a perception of their position being threatened on the home market, some due to perceived foreign business opportunities, and some due to a combination of the two (Loustarinen, 1979). This gives us reason to believe that the BTF offers an important piece in the puzzle that could make up such a general conceptual framework.

\section{Aspiration levels and Problemistic Search}

The theory of performance relative to aspiration levels depicts firms' decision-making as a sequential process where performance is compared with a goal, initiating problemistic search if performance is low relative to the goal, and making strategic changes if a satisfactory solution is found (Cyert and March. 1963; Greve, 2003b). The core of these arguments is about searching for alterations in strategy in order to meet some satisfactory point of output. Reasons to initiate change might be that a problem appears in the firm's current operations, for example a performance shortfall. Regardless of the initial problem, a search process is involved - either this search is triggered by problems, such as decreasing domestic markets, or by slack, such as available resources to pursue foreign opportunities. In this study we lack good empirical measures of organizational slack and therefore limit our focus to that of problemistic search.

Problemistic search is first and foremost conducted in the proximity of the immediate problem and current activities of the organization. For example, if the perceived problem is a shortfall in revenue relative to what the firm aspires to, natural solutions would be to search for ways to increase the efforts and mandate of the sales force. Other solutions would be to expand into industrial subfields or other geographic areas (Baum, Li and Usher, 2000). The general state of, and trends within, an industry is also important in how a firm will respond to low performance (Spender, 1989). If the industry has little or no prior history of conducting international business, other factors such as improvements in sales personnel, product mix, or operations are more likely 
responses. Conversely, if a firm's industry is currently experiencing a phase of increased internationalization in which the firm has not yet taken much part, sudden shortfalls in performance are likely to lead the firm's attention to its lack of international operations. Our conceptual model, with related hypotheses, is outlined in Figure 1.

\section{--- INSERT FIGURE 1 HERE ---}

\section{Hypotheses Development}

\section{Aspiration levels and Search}

Jones and Coviello (2005) describe internationalization behavior as a process influenced by (i) the individual entrepreneur, (ii) her firm, and (ii) the external environment. Specifically, they note that the internationalization processes are iterative as a result of learning from previous behavior and performance (p.289). At the onset of our data collection we worked inductively by interviewing a sub-sample of four firms. We found that internationalization was not a distinct process separated from other strategic decisions within the firm. On the one hand, a strategy of rapid internationalization could easily be abolished or delayed given changes in performance. When domestic orders increased, plans for internationalization were sometimes put on hold due to resource restrictions. On the other hand, internationalization was sometimes regarded as a rescue avenue when performance decreased, leading firms to devote scarce resources to internationalization measures. Similar to findings in other studies, some firms indicated that decreasing margins in their home market was a key trigger in their decisions to search for new international business opportunities (Boter and Holmquist, 1996; Lindell and Karagozoglu, 1997; Loustarinen, 1979). These findings lend some preliminary support to the validity of performance- 
feedback theory in an international entrepreneurship setting, leading us to formulate our first hypothesis:

Hypothesis 1: If performance relative to aspiration level decreases, problemistic search will increase.

\section{Aspiration levels and internationalization}

The BTF also predicts that not only search for solutions, but also preferences between solutions will change in response to performance feedback since shortfall in performance will simultaneously affect the organization's risk preference. That is, when performance falls short of the aspiration level, awareness of needs of organizational improvement and new ways of conducting business will increase, stimulating risk taking and experimentation with new solutions (Cyert and March, 1963). For firms that consider international venturing as a means of expanding their firms and solve the perceived performance gap, internationalization can lower managers; perceptions of risks (Zahra, Hayton, Marcel \& O'Neill, 2001). Our second hypothesis therefore predicts that performance below the aspiration level will also have a direct effect on internationalization activities by increased risk taking:

Hypothesis 2: If performance relative to aspiration level decreases, internationalization attempts will increase.

\section{Active search and internationalization}

Our expectations about the relationship between performance below aspiration levels and an increase in number of internationalization attempts is based on the argument that relative performance is the key determinant of the firm's risk preference. Changes in risk preference, 
however, do not tend to generate new solutions per se, but rather act as a moderating factor depending on whether solutions are assessed as attractive.

What determines the stock of solutions that a firm can generate to solve a perceived problem is how much effort is put into investigating alternative solutions. Regardless of the longterm success of these solutions, initiation of search will generate more possible solutions to remedy the firm's problem. It is therefore more in line with our theory to focus on attempts to initiate/expand international operations and not the actual scope or outcome of such operations. Thus, we predict:

Hypothesis 3: Initiation of search will lead to an increase in internationalization attempts.

\section{Methods}

\section{Sample}

This study uses data on internationalization processes drawn from the INTERSTRATOS program with annual surveys to small firms in seven European countries for each of the years 1991-1995 (see Haahti, Hall and Donckels, 1998 for an in-depth description; for a recent study using INTERSTRATOS data, see Voerman, 2004). In this paper we use only the Swedish data for three reasons: First, the Swedish dataset was designed to allow individual firms to be identified and followed over all five years. Second, while conducting exploratory case studies and participating in the outlining and designing of the Swedish surveys, we gained in-depth familiarity with the dataset, both its strengths and weaknesses. Third, the annual response rates vary much between countries, with Sweden, Austria and the Netherlands showing by far the highest response rates. 


\section{Survey Design and Data Collection}

To gain an understanding of internationalization processes in the industries covered in this study we personally contacted the CEO/manager of ten firms active in the electronics, textiles, furniture, food, or medical components industries at the onset of this study. Four firms chose to participate, one from each industry except from the food industry that also had the lowest level of exports and the highest level of domestic market focus. In each firm, two researchers interviewed the person 'responsible for internationalization' using a semi-structured interview format. The two researchers met to validate interpretations of the findings with each other. The interviews lasted between three and four hours, and were taped and transcribed in full. The transcriptions were posted to the respondents who commented further upon these. On several occasions we phoned back to fill in gaps in our material. The qualitative data enabled us to gain better familiarity with how international activities are initiated in small firms, and also helped us assess the internal validity of some of the crucial variables used in the survey.

In April 1991, surveys were sent to a random sample of 2,468 newly started small-and medium-sized firms stratified by size class and industry. In order to reach a convenient sample size and to limit unobserved heterogeneity, only firms belonging to the electronics, textiles, furniture, food or the medical components industries were considered. The sample was surveyed each April for the following four years with an average response rate of $36.5 \%$. It was apparent that the economic recession during the period affected the sample, especially in 1993 when 389 of 2362 firms closed down due to liquidation and/or bankruptcy. The sample size and response rates are outlined in Table 1. 
The survey was sent to all firms still in existence during each of the five years regardless of whether they answered the previous year's survey. Therefore, responses are in many cases available only for one or two years, or at irregular time periods (i.e. 1991 and 1993). The total data set collected thus constitutes an unbalanced panel with a total of 4,054 firm-year observations. Since our theoretical model in this paper is founded on the view of firm behavior as an incremental process where change is stimulated by below-aspiration performance, longitudinal data on performance and behavior is crucial. To satisfy this condition without discarding the bulk of our data we excluded firms with only a single observation and below we also try to statistically correct for firms' attrition from the sample for those instances when a firm returned two, three or four surveys but then stopped answering.

To avoid problems of endogeneity, we tested for the effect of performance relative to aspiration levels in a given year on search behavior and internationalization attempts (activities to increase international sales, etc.) in the succeeding year. This lag decreased the available data period to 1992-1995 (2,355 firm-year observations) since we have no data in 1990 to infer strategic actions taken in 1991.

\section{Measures}

Our behavioral model of internationalization includes two dependent variables: problemistic search and number of internationalization activities.

Problemistic search. The exploratory case study data indicated that several of the small firms searched for internationalization opportunities either proactively (for example, by opening up a sales office abroad) by starting to export using personal contacts to get access etc, or reactively (for example, by imitating a competitor that started exporting) by responding to initiatives taken by customers abroad etc. We therefore used a trinomial measure of search activity in the survey: 
"Have you searched for internationalization opportunities in the past twelve months?" with the answers being "Yes, actively", "Yes, passively", or "No". The current study considers only occasions indicating active search. A dummy variable taking the value one if active search took place represents our first dependent variable.

\section{Internationalization.}

A large variety of studies have measured internationalization in small firms in various ways. McDougall \& Oviatt (2000) defines International entrepreneurship as “a combination of innovative, proactive, and risk-seeking behavior that crosses national borders and is intended to create value in organizations" but do not include any specific definitions of such activities. In this paper we therefore rely on Jones and Coviello (2005) who provided more specific suggestions how to measure internationalization in addition to the conventional outward entry modes of exporting: for example by including into our measure of internationalization occasion when firms start licensing and receive as well as conduct foreign direct investment (cf. Knight \& Cavusgil, 2004) as well as occasion when firms engage in financial co-operation or formal alliances with domestic partners in order to expand internationally (Fernández \& Nieto, 2005). Following the suggestion to "rather than place [internationalization] modes into predetermined ranks or assumptions of order, we suggest that it is more appropriate to incorporate known measures of cross-border business modes to determine representative composite measures of crossborder activity undertaken by a firm" (Jones \& Coviello, 2005: 292) we choose to investigate a broad spectrum of potential internationalization activities available to new and small firms. As our second dependent variable, number of internationalization activities, we therefore measure by nine dichotomous questions on new types of international activities initiated during the past twelve months (outlined in Appendix 1, see also Haathi et al., 1998). We use the sum of these activities as our second dependent variable, i.e. an ordinal-scaled variable zero-nine. Compared to 
dichotomous measures of activities such as initiation of new sales offices or joint ventures, our measure has the advantage that it considers that such activities might or might not take place in specific sequences, and that there is substantial heterogeneity in the importance that individual firms put on these activities. Compared to other alternative measures usually employed in internationalization research such as change in export budget or export ratio, our dependent variable is not at risk of being conflated by changes in, for example, sales budget or the firm's overall revenue.

\section{Independent variables}

Theoretical and empirical research drawing upon the BTF has gone a long way in theorizing about how aspiration levels are formed, and testing different ways to measure this empirically (Greve; 2003b; Levinhthal and March, 1981). Measuring aspiration relative to performance requires, firstly, a theoretically valid measure of aspiration levels, and secondly, a performance measure that is comparable across firms.

Performance. Most prior aspiration-level performance research uses standardized measures of firm performance such as return on assets (Baum et al., 2005, Greve, 2003a). Because our survey instrument does not include the balance-sheet data necessary to calculate return on equity or assets, we considered alternative measures of performance that were readily comparable across firms. We base our reasoning on the argument that financial performance measures are generally less relevant for small and new firms (Van de Ven, Hudson, and Schroeder, 1984). Many young firms show no profit altogether in the first few years, for example by pursuing growth strategies rather than focusing on profitability (Zahra, 1991). The exploratory case studies, as well as our own professional experience told us that, in new and small firms, revenue and an increase in sales are a key focus. The main reasons are that it may take time to 
reach long-term profitability and that small firms depend on increasing revenue to allocate fixed costs. We therefore decided to use revenue (measured in hundred-thousands Swedish krona) as the performance variable.

Aspiration level: Aspiration levels are shaped by two joint forces: the firm's prior performance history and comparison with similar firms (Cyert and March, 1963; Levinthal and March, 1981). Performance history is generally calculated by measuring some type of weighted moving average, where more weight is given to recent years (Greve, 2003b; Levinthal and March, 1981). Since existing literature and preliminary analyses of our data indicated that social comparison make up the lion's share of a firm's aspiration level, we did not include performance history beyond that of the last period. We used performance of the focal firm for the preceding year T-1 combined with a measure of social comparison at the current year $\mathrm{T}$, decreasing the data to a final of 1,750 firm-year observations for our analyses of new internationalization attempts. Social comparison is generally considered to consist of comparison with 'similar others' (Festinger, 1954). In the aspiration-level literature, this is traditionally measured as the mean performance of all firms in the same industry as a focal firm (Greve, 2003b). This is also the measure we employ in this study, computing the mean yearly performance of all firms active in the electronics, textile, furniture, food or medical components industries. Since prior aspiration level studies indicate slightly different relative proportions of performance history and social comparison depending on industry context (Baum et al., 2005; Greve, 2003b; Greve, 2003c) we searched for the best combination by varying the weights of performance history and social comparison in increments of 0.1 , deciding on the proportion yielding the highest model fit (loglikelihood value), which similarly to Greve (2003c) was a nine to one proportion of social comparison relative to performance history of the overall aspiration level ${ }^{1}$. To test for different effects on internationalization of performance above and below a specific firm's aspiration level, 
we specify performance as a spline function by using separate variables for performance above (AboveAsp) and below (BelowAsp) the aspiration level (Greve, 2003a). This allowed us to test our hypotheses by comparing the coefficient slopes for the two different variables. Since values for the variable BelowAsp falls at or below zero, we followed Baum et al's (2005) procedure and reverse code the variable for easy of interpretability.

\section{Control variables}

Weeks traveled abroad. To control for the possibility that search was initiated before a performance downfall, we try to control for the fact that search for new activities might have begun "informally". We asked each manager how many weeks they had traveled abroad during business in the previous year.

Local market focus: To control for the fact that firms differ in their international scope during the start of the study, we include a variable measuring the firm's proportion of sales on the local market.

Firm size. Number of employees controls for firm size.

Industry. Five industry dummies, for each of the electronics, textiles, furniture, food, and medical components industries were used to ascertain that our results would not be driven by industry differences.

Entrepreneurs' education. We use years of schooling to control for education of the firm founder/manager.

Experience. We include number of years of industry-specific experience. This controls for specific human capital of the individual founder/manager - an important factor affecting new ventures internationalization (Westhead, Wright and Ucbasaran, 2001). 
Entrepreneurs' sex: A dummy variable is used to control for sex of the firms' founder/manager, diminishing heterogeneity in human capital and education.

Sample selection correction. A significant portion of the firms in our sample stopped responding to the survey before the end of the study period. We cannot rule out the possibility that these non-respondents differ systematically from respondents, for example they could be less interested in internationalization altogether, or too busy with their ongoing internationalization activities to answer repeated surveys. In addition, over a fifth of the original sample (509 of 2468 firms) disappeared throughout the study period due to bankruptcy or liquidation. Since firms with deteriorating performance are more likely to disappear, inferences on firms development and change using aspiration-level performance theory are susceptible to sample selection bias (Denrell, 2004). To control for the possibility that firms that exit the sample exhibit different patterns of aspiration-level performance and internationalization attempts, we use a Heckmantype selection model to create a variable that corrects for firms self-selection as survey respondents. Since the error term in the first stage of the equation (the self-selection decision) is not normally distributed, we use Lee's (1983) generalization of the Heckman procedure by estimating a logit model of attrition from the sample, including the transformed logit predictions in the form of Inverse Mills Ratios as a selection variable in the final model (Lee, 1983). The logit model used to predict the likelihood of attrition from the sample and to compute the Inverse Mills Ratios should preferably include at least one variable that influences the probability of attrition from the sample, but is uncorrelated with both of our dependent variables: search and internationalization attempts. We first include two characteristics that are likely to influence firms' resource base and their general ability to search for international business opportunities: firm size (employees) and prior export rate (0-100\%). We also include the answers to two Likert- 
scaled variables measuring the opinion towards firm strategy and internationalization, taken from the perception-based part of the survey: "a firm should keep focus at its home base", and “managers should take personal responsibility for their decisions", both measured on a 0-5 scale.

\section{Statistical analyses}

Our analyses took advantage of the panel structure of the data, which allowed us to account for two fundamental issues - the possibilities of controlling for time-invariant unobserved heterogeneity between firms and the possibility of modeling dynamic relationships among variables. We experimented with different lagged effects of how performance below aspiration levels affected short-term and long-term internationalization attempts, but settled on a traditional one-year lagged effect to take account of the inertia common in firms' budget allocation processes, and to avoid endogeneity problems. Seemingly similar firms might differ on some characteristic that we fail to observe or cannot measure. A way to correct for such unobserved heterogeneity is to use random- and fixed-effects estimation. We conducted a Hausman (1978) test that failed to show significance, leading us to favor random effects estimation. For comparison purposes, we also include a fully saturated model using all the variables, estimated by fixed effects. The first dependent variable, problemistic search, is a dichotomous indicator of whether a firm undertook active search for new ways to go international during a given year. To investigate the role of performance relative to aspirations in triggering such search, we estimated random-effects logit models. These models produce coefficient estimates that can be converted into odds ratios to predict relative frequencies just like logistic regression (Hosmer and Lemeshow, 2000).

Our second dependent variable, number of internationalization activities, was measured by adding nine different types of internationalization activities that a firm had initiated during the 
past 12 months (for details, see Appendix 1). By definition this variable will only take on nonnegative integer values. This suggests some type of Poisson regression should be appropriate. Two problems commonly associated with Poisson-type models are overdispersion and many zero counts for the dependent variable. A true Poisson model assumes that the distribution of the outcome variable has a mean equal to its variance, which is part of the definition of a Poisson distribution. A conditional mean that is greater than the conditional variance is referred to as 'overdispersion'. Overdispersion can be detected by comparing the reported model's Chi-2 statistic with its degrees of freedom, An overdispersed model will have a ratio greater than 2 . If the variance assumption does not hold - as is very often the case - we must make some specific parametric assumptions about the way the variance differs from the mean (e.g. to assume that the variance is linear or quadratic in the mean). The ability to specify such an assumption is the idea about the negative binomial (negbin) model, a frequent alternative to Poisson regression. The second possible problem, many zero counts in the data, indicates a possibility that the zero outcome is fundamentally different to the numeral outcomes. If there is a qualitative difference between transition from zero events to the first occurrence, and from the first occurrence to further occurrences, a zero-inflated model might be appropriate (Greene, 1994). For example, it is plausible that a firm does not, as we have hypothesized, search for different ways to increase the portfolio of international activities, but rather decides beforehand if to increase internationalization or not, and if the decision is 'Yes' they subsequently chooses what type of internationalization activities to initiate. In addition, it is possible that some firms underreported their number of internationalization activities. In cases of underreporting, zero-inflated models should be preferred to ordinary Poisson-type models (Greve, 2003a).

Preliminary analysis revealed evidence of both overdispersion and 'excess zeros'. To investigate overdispersion, we fitted initial Poisson models that indicated a ratio of Chi-2/d.f. 
exceeding 5.7. We therefore decided to disregard the Poisson model in favor of a negbin model. To determine whether the existence of excess zeros in the dependent variable signify that zeroinflated models are a more accurate description of a firm's underlying choice-set of engaging in internationalization activities, we used Vuong's (1989) test statistic for non-nested models which follows a standard normal distribution where $|\mathrm{V}|>1.96$ supports the zero-inflated model, whereas large negative values $(|\mathrm{V}|<-1.96)$ support the standard negbin. Testing the models against each other revealed a Vuong test statistic of 0.046 that clearly does not favor either model. Reported models therefore follow the ordinary negbin type. In all analyses we verified the findings with zero-inflated models and related Wald tests for hypotheses testing, indicating no qualitative differences between zero-inflated and non zero-inflated models.

According to Blundell, Griffith and Van Reenen (1995) the negbin model leads to consistent estimators if there is some heterogeneity in the data but no permanent unobservable effects. Permanent heterogeneity will display itself through persistent serial correlation in the residuals (Blundell et al., 1995: 336). We investigated serial correlation in our data through looking for correlation over time in the residuals. This revealed the existence of serial correlation in the independent variables, significant at the one per cent level. We therefore also estimated population-averaged version of the negbin model. The population-averaged model is of the type generalized estimating equations (GEE), which employ quasi-likelihood estimation in a panel context by looking for time-varying deviations from the sample means (Liang and Zeger, 1986). This method allows for robust variance estimation (i.e. the Huber/White sandwich estimator) and controls for serially correlated data. Since unequally spaced observations are excluded by serially correlated GEE models, only 1,195 observations from 410 firms were analyzed. The results are included for comparison with the main random-effects and the fixed-effects models. The results of the population-averaged and the random-effects negbin models were qualitatively very similar, 
indicating that autocorrelation, and hence time-invariant unobserved heterogeneity between firms, was not a major issue. ${ }^{2}$

\section{Results}

Using past performance for calculating aspiration levels predicting future search and increased internationalization left us with three years with full data. All variables together with their mean standard deviations are shown in table 2 . VIF values were well below critical values and did not indicate any presence of multicolinearity.

\section{--- INSERT TABLE 2 HERE ---}

Table 3 shows the logit models predicting search for new internationalization activities. Performance relative to aspiration level, introduced in model 2 (search), reveals the expected positive relation to search for internationalization activities when performance falls below the aspiration level. Performance above the aspiration level also seems to have a positive impact on internationalization activities. This indicates that firms with median-level performance are less prone to search compared to firms performing above or below their aspiration levels, consistent with the predictions of performance-feedback theory that performance relative to the aspiration level would lead to some type non-homogenous pattern of problem and slack-driven search efforts (Greve, 2003a). In this case, the positive coefficients for both AboveAsp and BelowAsp indicate an effect on search according to a flat and unevenly $\mathrm{V}$-shaped pattern, similar to that found by Baum and colleagues (2005). The slope for BelowAsp is almost twice that of AboveAsp, and an F-test of mean effects indicates a significant $(p<.05)$ difference between the two variables, supporting the idea that performance below the aspiration level stimulates risk 
taking more than performance above the aspiration level (Kahneman and Tversky, 1979). In the discussion section we return to discuss the role of performance above the aspiration level.

\section{--- INSERT TABLE 3 HERE ---}

The models thus support our first hypothesis, which predicts an increasing rate of search for performance below the aspiration level. The coefficients of performance above and below aspiration level are significantly different and the model fit statistics show a clear increase in 'log-likelihood' and variance explained when performance is entered, suggesting that performance is a crucial determinant of a firm's search for internationalization activities. The inverse Mills ratio is positively related to search, significantly below the one percent level. This indicates that firms with a high likelihood of disappearing from the sample (lower inverse Mills ratio) search less than other firms. We interpret this as a sign of threat rigidity (Audia and Greve, 2006). Firms with a high likelihood of disappearing from the sample, for example those that approach near bankruptcy or liquidation, decrease their search efforts and focus primarily on organizational survival (Cyert and March, 1963).

We now turn to investigate the effect of aspiration-level performance and search on increased internationalization attempts. Table 4 reports the results of our series of random-effects negbin models together with results of a fixed effects model and a GEE model with controls for serial correlation. Introducing firstly the control variables and subsequently the aspiration-level variables in the second (aspiration) model, we find that performance below the aspiration level exhibits clear positive effects on the number of new internationalization attempts. In these models performance above the aspiration level is insignificant, and an F-test of mean effects indicates a significant $(p<.001)$ difference between AboveAsp and BelowAsp. This supports our second 
hypothesis. Since our theoretical model in Figure 1 depicts search as an intermediate variable between performance relative to an aspiration level and internationalization attempts, we introduce search separately in the third (search) model, followed by all variables in the fourth (full) model. In both the third and the fourth models we find that search, as hypothesized, has a positive impact on new internationalization attempts. This supports our third hypothesis. Finally, the fixed effects model and the GEE model with control for serial correlation indicates qualitatively identical effects, albeit somewhat weaker in the fixed effects model.

\section{--- INSERT TABLE 4 HERE ---}

The question then is, are these findings important explanations of firms' internationalization attempts? When interpreting the coefficients in Table 4, the outcome variable for our count model is really the natural $\log (\log$ base $e-$ the power that $e$ has to be raised to in order to get the original number, where $e$ is about 2.718) of the number of internationalization activities. A more accessible way to interpret these estimates is to think of the percentage change in the outcome count $(\mathrm{Y})$ expected for each one-unit increase in a numerical independent variable (X) amounting to 100 times the inverse natural $\log$ of the coefficient minus 1

$\left(\Delta Y \%=100 \times\left[e^{X}-1\right]\right)$. Using this procedure, we find that the expected number of internationalization activities increases by 8.82 percent for each million Swedish krona ${ }^{3}$ that performance falls short of the firm's aspiration level. Since the standard deviation of this variable is 2.39 million krona for the firms in our sample, it is clear that performance relative to aspiration levels - as indicated by the BTF - acts as a key determinant of increased international entrepreneurship. 
Interpreting the effect of independent variables in dummy form, such as the effect of search on internationalization attempts, is somewhat more complicated since using the above procedure to calculate marginal effects only shows the relative change when the dummy variable changes from 0 to 1 . Using this procedure in our final negbin model reveals that when search goes from 0 to 1 , the number of expected internationalization activities increases by 57 percent.

\section{Discussion}

In this paper we have introduced and provided a first empirical test of aspiration-level performance theory in internationalization research. Using behavioral theory and findings from four inductive case studies to guide our theorizing, we hypothesized that performance below aspiration levels would induce problemistic search for ways to go international, and where search should increase the possibility of firms finding new ways to achieve increased internationalization. The theoretical model was tested on a panel of 860 Swedish firms that we surveyed annually for five years during the economic downturn of the early 1990s. We tested our hypotheses using logit models to determine the effects on search behavior by performance below or above the firm's aspiration level, and negative binomial models to determine the joint effect of aspiration-level performance and search on new attempts to initiate international operations. We found that performance below aspiration levels increased the firms' search for opportunities to internationalize, and that both search behavior and performance below aspiration levels had a distinct influence on new internationalization attempts.

We were also able to notice in Table 3 that the search for internationalization attempts seemed to be positively affected both by performance falling short of the aspiration level and by performance exceeding the aspiration level, i.e. that performance relative to aspiration levels exhibit a V-shaped effect on search, with intermediate levels of performance having the smallest 
effect on search. This is consistent with behavioral theory and prior empirical work (e.g. Greve, 1998). However, the effect of performance exceeding the aspiration level is cancelled out when considering both search and performance relative to aspirations in Table 4. This indicates the existence of some intermediate variable that affects internationalization in a positive way for performance above the aspiration level, but is moderated by search. Although we do not yet know enough to ascertain the full causal chain, the BTF clearly points to slack and slack search as plausible candidates for these intermediate variables.

We began our theoretical exposition in this paper with the notion that, although behavioral arguments are common in internationalization research, applied empirical work has often ignored several of the key theoretical components of the BTF: risk avoidance, search, and heterogeneous aspirations. This study is the first that we know of that offers empirical evidence for the viability of the BTF in international business research. A key component of our theoretical model is that firms seek to uphold a relative status quo in a competitive market, and that internationalization need not be the result of a mature home market, nor require abundant resource bases. Our findings that internationalization is stimulated by problemistic search following below-aspiration performance therefore offer alternative perspectives to studies in international entrepreneurship using resource-based (Westhead, Wright and Ucbasaran, 2001) or resource-dependency frameworks. New entrepreneurial firms occasionally seek for opportunities to internationalize operations, and we find that discontentment with current revenues was a stronger motivator for such opportunity search than steadily rising revenues in the home market. Our study therefore offers an encouraging position for new and small firms distressed by current earnings: Yes, it is possible to expand internationally despite lack of resources. 


\section{Conclusion and further research}

This study contributes to international entrepreneurship theory by introducing and testing the prevalence of performance-action feedbacks as explained by the BTF. Using logistic regression and count data analysis to test a behavioral model of internationalization, our study indicates that performance relative to aspiration level is an important factor in the internationalization processes. We offer a theoretical framework and an important first empirical attempt to demonstrate the viability of the aspiration-level performance theory in small firms' internationalization.

However, our study also comes with several limitations, all which offer important paths for future research attempts. Firstly, we use only a subset of the surveyed firms. Analysis of unbalanced panels, or some type of data imputation, might provide a much larger sample size and thus better generalizability. Secondly, many of our measures could be validated or developed by using secondary data such as annual reports which currently were not accessibly since we surveyed the firms anonymously to ensure a large response rates and non-bias in responses.

. Our empirical test would be strengthened by controlling for resources beyond that of firm size in terms of revenue and employees, and also for competing outcomes of performance below aspiration levels, such as changes in product development. Thirdly, our sample was collected during a period of adverse economic conditions for most Swedish small- and mediumsized firms. In particular, the mean firm's revenue decreases by about 10 percent annually from 1991 to 1995 for firms in this sample, making inferences based on the revenue of these firms an ideal case for tests of problemistic search. However, this also puts a limit on the generalizability on the results. Although the sample is a representative sample of Swedish small- and mediumsized firms with satisfactory response rates, the behavior that we observe in these firms might be quite specific for the adverse business conditions that they faced. More research on problemistic 
search during other parts of the economic cycle and in other countries and for other industries, are needed. Fourthly, a theoretical gap in this paper is that we only consider problemistic search, and not its affluent counterpart, slack search. Our tentative findings related to performance above the aspiration level suggests that a natural and important extension of our model is jointly to consider the effects of problemistic search and slack search, respectively, on internationalization. It is also possible that the geographic and psychic proximity of host countries influence search behavior, something that future studies might shed light on.

In sum, we have outlined a behavioral model where firm performance below an aspiration level triggers search for new ways to increase overseas sales. We tested our model on a stratified random sample of 860 Swedish small- and medium sized firms that we followed for five years, receiving strong support for our hypotheses. We also found indications that slack search might be an equally important factor in small firms' search for opportunities to internationalize. These findings point to several exciting opportunities for expanding the scope of aspiration-level performance theory in international entrepreneurship research. 


\section{REFERENCES}

Acedo, F.J. \& Jones, M.V. 2007. Speed of internationalization and entrepreneurial cognition: Insights and a comparison between international new ventures, exporters and domestic firms Journal of World Business, 42 (3), 236-252.

Acs, Z., Dana, L.-P. \& Jones, M.V. 2003. Towards new horizons: The internationalization of entrepreneurship. Journal of International Entrepreneurship, 1 (1), 5-12.

Andersen, O, 1993. On the internationalization process of firms, A critical analysis, Journal of International Business Studies, 24 (2), 209-232.

Andersson, S. 2000. The Internationalization of the Firm from an Entrepreneurial Perspective, International Studies of Management and Organization, 30 (1), 63-92.

Audia, P. and Greve, H. 2006. Less Likely to Fail, Low Performance, Firm Size, and Factory Expansion in the Shipbuilding Industry. Management Science, 52 (1), 83-94.

Augier, M., and March, J. G. 2003. The economic psychology of Herbert A. Simon, Introduction to a special issue, Journal of Economic Psychology, 24 (2), 135-141.

Autio, E., Sapienza, H. J., and Almeida, J. G. 2000. Effects of age at entry, knowledge intensity, and imitability on international growth, Academy of Management Journal, 43 (5), 909-924.

Baum, J. A. C., Li, S. X., and Usher, J. M. 2000. Making the next move, How experiential and vicarious learning shape the locations of chains acquisitions, Administrative Science Quarterly, 45 (3), 766-801.

Baum, J. A. C., Rowley, T., Shipilov, A., and Chuang, Y.-T. 2005. Dancing with Strangers, Aspiration Performance and the Search for Underwriting Syndicate Partners, Administrative Science Quarterly, 50 (4), 536-575.

Bilkey, W.J. 1978. An attempted integration of the literature on the export behavior of firms, Journal of International Business Studies, 9 (1), 33-46.

Bingham, C. and Eisenhardt, K. 2005. Learning from heterogenous experience, The internationalization of entrepreneurial firms. Working paper, Stanford University.

Boter, H. and Holmquist, C. 1996. Industry characteristics and internationalization processes in small firms, Journal of Business Venturing, 11 (6),471-487.

Blundell, R., Griffith, R., and Van Reenen, J. 1995. Dynamic Count Data Models of Technological Innovation, Economic Journal, 105 (429), 333-344. 
Busenitz, L., and Barney, J. 1997. Difference between entrepreneurs and managers in large organizations, Biases and heuristics in strategic decision making, Journal of Business Venturing, $12(1), 9-30$.

Cooper, A.C., Folta, T.B., and Woo, C. 1995. Entrepreneurial Information Search, Journal of Business Venturing, 10 (2), 107-120.

Coviello, N.E. and McAuley, A. 1999. Internationalisation and the Smaller Firm, A Review of Contemporary Empirical Research, Management International Review, 39 (3), 223-256.

Cyert, R. M., and March, J. G. 1963. A behavioral theory of the firm. Englewood Cliffs, N.J., Prentice-Hall.

Denrell, J. 2004. Risk taking and aspiration Levels, Two alternative null models. Best Paper Proceedings, Academy of Management, New Orleans.

Fernández, Z. \& Nieto, M.J. (2005). Internationalization Strategy of Small and Medium-Sized Family Businesses: Some Influential Factors. Family Business Review, 18 (1), 77-89.

Festinger, L. 1954. A theory of social comparison processes, Human Relations, 7, 117-140.

Gimeno, J., Folta, T. B., Cooper, A. C., and Woo, C. Y. 1997. Survival of the fittest? Entrepreneurial human capital and the persistence of underperforming firms, Administrative Science Quarterly, 42 (4), 750-783.

Greene, W. H. 1994. Accounting for excess zeros and sample selection in poisson and negative binomial regression models. Working paper EC-94-10, New York University.

Greve, H. R. 1998. Performance, Aspirations and Risky Organizational Change, Administrative Science Quarterly, 43 (1), 58-86.

Greve, H. R. 2003a. A behavioral theory of RandD expenditures and innovations, Evidence from shipbuilding, Academy of Management Journal, 46 (6), 685-702.

Greve, H. R. 2003b. Organizational Learning from Performance Feedback, A Behavioral Perspective on Innovation and Change. London, Cambridge University Press.

Greve, H. R. 2003c. Investment and the behavioral theory of the firm, evidence from shipbuilding, Industrial and Corporate Change, 12 (5), 1051-1076.

Haahti, A., Hall, G. and Donckels, R. 1998. The internationalization of SMEs, the Interstratos project. London, Routledge.

Hausman, J. 1978. Specification Tests in Econometrics, Econometrica, 46, 1251-1272.

Hosmer, D. and Lemeshow, S. 2000. Applied logistic regression. New York, Wiley. 
Johanson, J. and Vahlne, J.E. 1977 The internationalization process of the firm, A model of knowledge development and increasing foreign market commitments, Journal of International Business Studies, 8 (1), 23-32.

Johanson, J. and Vahlne, J.-E. 2003 Business relationship learning and commitment in the internationalization process, Journal of International Entrepreneurship, 1 (1), 83-101.

Jones, M.V. and Coviello, N.E. 2005. Internationalization: Conceptualizing an Entrepreneurial Process of Behaviour in Time, Journal of International Business Studies, 36(3): 284-303.

Kahneman, D., and Tversky, A. 1979. Prospect theory, An analysis of decision under risk, Econometrica, 47 (2), 263-291.

Knight, G.A. and Cavusgil, S.T. 2004. Innovation, Organizational Capabilities, and the BornGlobal Firm, Journal of International Business Studies, 35 (2), 124-141.

Lee, L. 1983. Generalized econometric models with selectivity. Econometrica, 51, (2), 507-512.

Leonidou, L.C. and Katsikeas, C. 1996. The Export Development Process, An Integrative review of Empirical Models, Journal of International Business Studies, 27 (3), 517-551.

Levinthal, D. A., and March, J. 1981. A model of adaptive organizational search, Journal of Economic Behavior and Organization, 2 (4), 307-333.

Liang, K.-L., S. L. Zeger. 1986. Longitudinal data analysis using generalized linear models, Biometrika, 73 (1), 13-22.

Lindell, M. and Karagozoglu, N. 1997. Global strategies of US and Scandinavian R\&D-intensive small- and medium-sized companies. European Management Journal, 15 (1), 92-100.

Madsen, T.K. 2005. Internationalization research, The impact of the Carnegie School, Scandinavian Journal of Management, 21 (4), 373-384.

Madsen, T.K. and Servais, P. 1997. The Internationalization of Born Globals, An Evolutionary Process? , International Business Review, 6 (6), 561-583.

McDougall, P.P., Shane, S., and Oviatt, B.M. 1994. Explaining the formation of international new ventures: The limits of theories from international business research. Journal of Business Venturing, 9 (6), 469-487.

McDougall, P.P. and Oviatt, B.M. 2000 International entrepreneurship, The intersection of two research paths, Academy of Management Journal, 43 (5), 902-906.

Melin, L. 1992. Internationalization as a strategy process, Strategic Management Journal, 13, 99119. 
Oviatt, B. and McDougall, P. 1994. Toward a theory of international new ventures, Journal of International Business Studies, 25 (1), 45-64.

Oviatt, B. and McDougall, P. 1999. Accelerated internationalization, Why are new and small ventures internationalizing in greater numbers and with increasing speed?, in R. Wright ed Research in Global Strategic Management, pp. 23-40. Stamford, CT, JAI Press.

Schoonhoven, C.B., Eisenhardt, K.M. and Lyman, K. 1990. Speeding Products to Market, Waiting Time to First Product Introduction in New Firms, Administrative Science Quarterly, 35 (1), 177-207.

Simon, H. A 1955. A behavioral model of rational choice, Quarterly Journal of Economics, 69 (3), 99-118.

Van de Ven, A., Hudson, H. R., and Schroeder, D. M. 1984. Designing New Business Startups, Entrepreneurial, Organizational and Ecological Considerations, Journal of Management, 101 (1), 87-107.

Voerman, J.A. 2004. The export performance of European SMEs, Unpublished Dissertation, University of Groningen, the Netherlands.

Vuong, Q. H. 1989. Likelihood ratio tests for model selection and non-nested hypotheses. Econometrica, 57 (2), 307-333.

Welch, L.S. and Loustarinen, R. 1988. Internationalization, Evolution of a Concept, Journal of General Management, 14 (2), 34-64.

Westhead, P. Wright, M. and Ucbasaran, D. 2001. The Internationalization of New and Small Firms, A Resource-Based View, Journal of Business Venturing, 16 (1), 51-75.

Zahra, S. 1991. Predictors and financial outcomes of corporate entrepreneurship, An explorative study, Journal of Business Venturing, 6 (4), 259-285.

Zahra, S., Hayton, J., Marcel J., and O'Neill, H. (2001). Fostering entrepreneurship during international expansion: Managing key challenges. European Management Journal, 19, (4), 359-369.

Zahra, S., and George, G. 2002. International entrepreneurship: The current status of the field and future research agenda, in M.A. Hitt, R.D. Ireland, S.M. Camp, and D.L. Sexton eds Strategic entrepreneurship, Creating a new mindset, pp. 255-288. Oxford, UK, Blackwell. 
FIGURE 1:

Behavioral model of internationalization

(tested relationships in bold arrows)

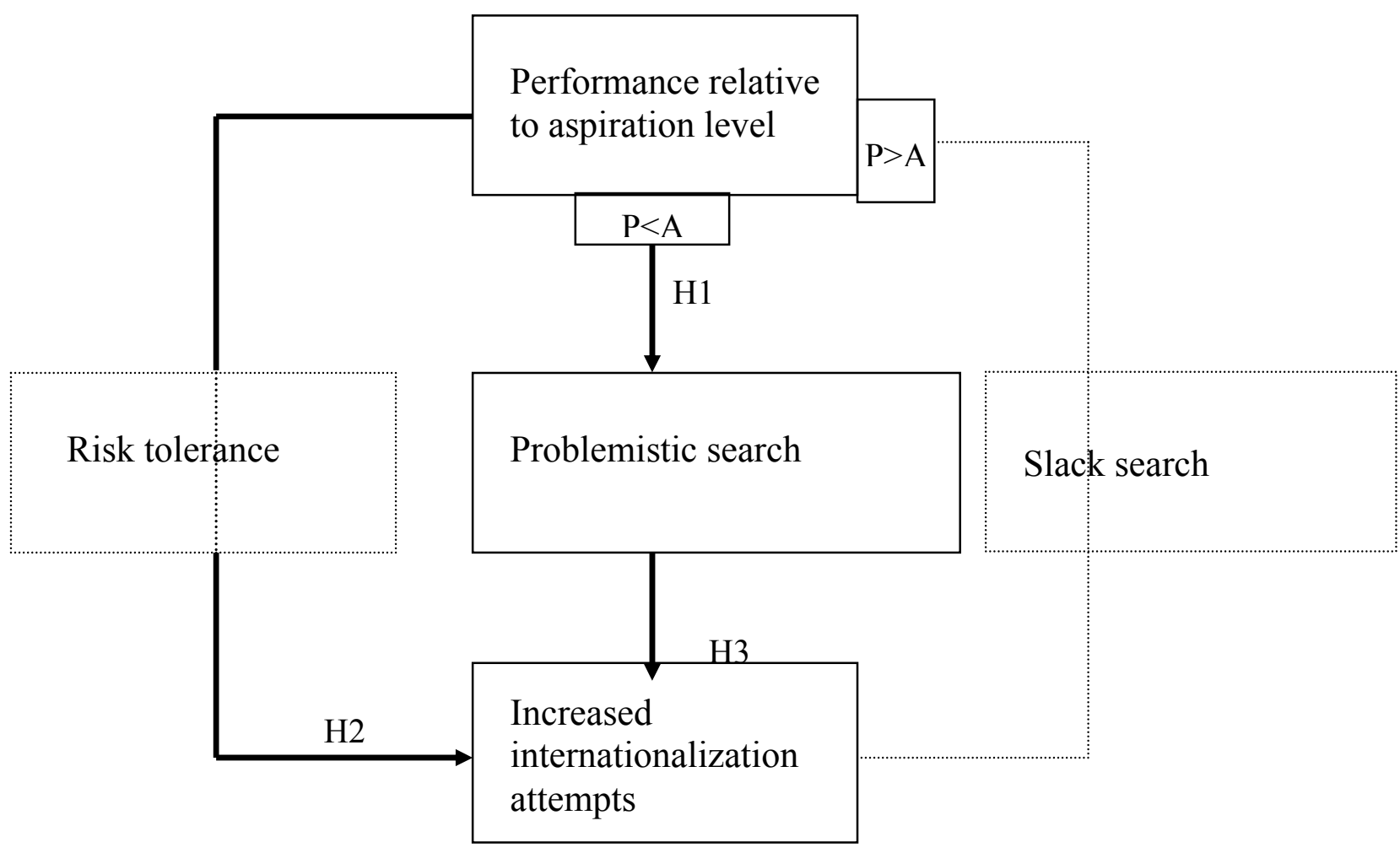

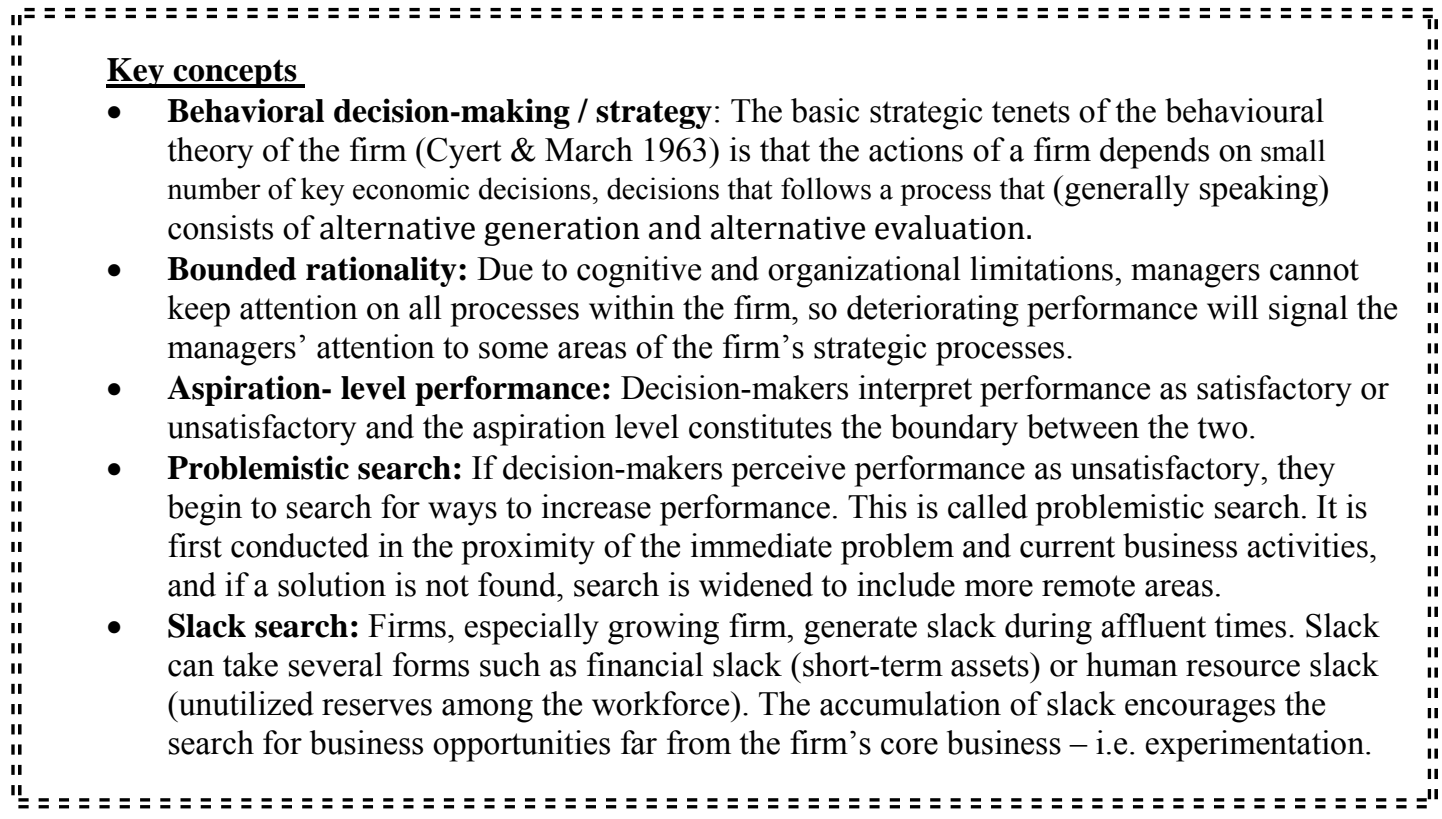


TABLE 1:

Sample size and annual response rates

\begin{tabular}{|l|l|l|l|l|l|}
\hline Year: & $\mathbf{1 9 9 1}$ & $\mathbf{1 9 9 2}$ & $\mathbf{1 9 9 3}$ & $\mathbf{1 9 9 4}$ & $\mathbf{1 9 9 5}$ \\
\hline \# of firm: & 2468 & 2400 & 2362 & 1973 & 1919 \\
\hline $\begin{array}{l}\text { Disbanded since } \\
\text { prior year: }\end{array}$ & 28 & 38 & 389 & 54 & N/A \\
\hline Remaining firms: & 2400 & 2362 & 1973 & 1919 & 1919 \\
\hline $\begin{array}{l}\text { Valid single-year } \\
\text { responses: }\end{array}$ & $\begin{array}{l}914 \\
(37.6 \%)\end{array}$ & $\begin{array}{l}845 \\
(35.7 \%)\end{array}$ & $\begin{array}{l}840 \\
(42.6 \%)\end{array}$ & $\begin{array}{l}727 \\
(37.9 \%)\end{array}$ & 731 \\
\hline
\end{tabular}

TABLE 2:

Variables and correlation matrix

\begin{tabular}{|c|c|c|c|c|c|c|c|c|c|c|c|c|c|c|c|c|}
\hline & Variable & Mean & S.D. & Min & Max & 1 & 2 & 3 & 4 & 5 & 6 & 7 & 8 & 9 & 10 & 11 \\
\hline 1 & IntActiv & 1.035 & 1.046 & 0 & 9 & & & & & & & & & & & \\
\hline 2 & AboveAsp & 8.544 & 53.501 & 0 & 1485.5 & 0.046 & & & & & & & & & & \\
\hline 3 & BelowAsp & -10.19 & 26.639 & -111.4 & 0 & -0.205 & 0.098 & & & & & & & & & \\
\hline 4 & Search & 0.350 & 0.477 & 0 & 1 & 0.345 & 0.127 & 0.191 & & & & & & & & \\
\hline 5 & Sex & 0.869 & 0.337 & 0 & 1 & 0.028 & 0.011 & 0.018 & 0.094 & & & & & & & \\
\hline 6 & Educatio & 5.930 & 6.874 & 0 & 35 & 0.322 & 0.074 & -0.057 & 0.135 & -0.003 & & & & & & \\
\hline 7 & Expernce & 19.334 & 12.312 & 0 & 60 & -0.110 & -0.038 & -0.069 & -0.107 & 0.103 & -0.173 & & & & & \\
\hline 8 & FirmSize & 51.697 & 87.175 & 1 & 998 & 0.084 & 0.369 & 0.231 & 0.335 & 0.087 & 0.072 & -0.153 & & & & \\
\hline 9 & LocalMkt & 24.248 & 34.118 & 0 & 100 & -0.162 & -0.088 & -0.203 & -0.363 & -0.016 & -0.085 & 0.101 & -0.225 & & & \\
\hline 10 & Weekabr & 9.314 & 11.324 & 0 & 135 & 0.196 & 0.084 & 0.084 & 0.299 & 0.084 & 0.085 & -0.124 & 0.211 & -0.149 & & \\
\hline 11 & Subsids & 0.387 & 0.487 & 0 & 1 & 0.120 & 0.082 & 0.141 & 0.243 & 0.084 & 0.094 & -0.255 & 0.294 & -0.168 & 0.165 & \\
\hline 12 & Inv.Mills & 1.344 & 0.502 & 0.323 & 2.637 & 0.157 & -0.005 & -0.115 & 0.038 & -0.027 & 0.259 & 0.025 & -0.029 & -0.052 & -0.011 & -0.008 \\
\hline
\end{tabular}

Note: All correlations exceeding \pm 0.06 significant at the $5 \%$ level 
TABLE 3:

Random effects logit models on search

\begin{tabular}{|c|c|c|c|c|c|c|}
\hline & Base model & & Full model & & $\begin{array}{c}\text { Fixed effects } \\
\text { model }\end{array}$ & \\
\hline Intercept & $\begin{array}{l}-3.200 \\
(0.402)\end{array}$ & $* * * *$ & $\begin{array}{l}-3.552 \\
(0.431)\end{array}$ & $* * * *$ & & \\
\hline BelowAsp & & & $\begin{array}{c}0.022 \\
(0.002)\end{array}$ & $* * * *$ & $\begin{array}{c}0.039 \\
(0.010)\end{array}$ & $* * * *$ \\
\hline AboveAsp & & & $\begin{array}{c}0.012 \\
(0.006)\end{array}$ & $* * *$ & $\begin{array}{r}0.014 \\
(0.004)\end{array}$ & $* * *$ \\
\hline Sex & $\begin{array}{c}0.260 \\
(0.268)\end{array}$ & & $\begin{array}{c}0.305 \\
(0.281)\end{array}$ & & $\begin{array}{l}-0.613 \\
(0.501)\end{array}$ & \\
\hline Educatio & $\begin{array}{c}0.038 \\
(0.011)\end{array}$ & $* * *$ & $\begin{array}{c}0.042 \\
(0.012)\end{array}$ & $* * * *$ & $\begin{array}{c}0.033 \\
(0.015)\end{array}$ & $*$ \\
\hline Expernce & $\begin{array}{c}0.005 \\
(0.008)\end{array}$ & & $\begin{array}{c}0.004 \\
(0.008)\end{array}$ & & $\begin{array}{c}0.005 \\
(0.015)\end{array}$ & \\
\hline FirmSize & $\begin{array}{c}0.004 \\
(0.001)\end{array}$ & $* * * *$ & $\begin{array}{c}0.002 \\
(0.001)\end{array}$ & & $\begin{array}{l}-0.007 \\
(0.005)\end{array}$ & \\
\hline LocalMkt & $\begin{array}{l}-0.024 \\
(0.003)\end{array}$ & $* * * *$ & $\begin{array}{l}-0.026 \\
(0.004)\end{array}$ & $* * * *$ & $\begin{array}{r}0.006 \\
(0.006)\end{array}$ & \\
\hline Weekabr & $\begin{array}{c}0.020 \\
(0.007)\end{array}$ & $* *$ & $\begin{array}{c}0.021 \\
(0.007)\end{array}$ & $* *$ & $\begin{array}{l}-0.005 \\
(0.012)\end{array}$ & \\
\hline Subsids & $\begin{array}{c}0.835 \\
(0.196)\end{array}$ & $* * * *$ & $\begin{array}{c}0.945 \\
(0.209)\end{array}$ & $* * * *$ & $\begin{array}{l}-0.148 \\
(0.455)\end{array}$ & \\
\hline Inv.Mills & $\begin{array}{r}0.119 \\
(0.041)\end{array}$ & $* *$ & $\begin{array}{r}0.056 \\
(0.053)\end{array}$ & $*$ & $\begin{array}{c}0.241 \\
(0.196)\end{array}$ & \\
\hline $\begin{array}{l}\text { Log } \\
\text { likelihood. }\end{array}$ & & & & & & \\
\hline $\begin{array}{l}\text { likelihood: } \\
\text { Firm-year }\end{array}$ & -1044.66 & & -1017.70 & & -176.19 & \\
\hline obs: & 2355 & & 2355 & & 564 & \\
\hline Firms: & 1127 & & 1127 & & 190 & \\
\hline$\Delta \mathrm{LR}$ & & & 53.92 & $* * * *$ & $\mathrm{~N} / \mathrm{A}$ & \\
\hline
\end{tabular}

Huber-White standard errors in parentheses. All models include industry dummies. a $p>0.10 ; * p>05 ; * * p>0.01 ; * * * p>.001 ; * * * * p>.0001$ (two-tailed).

$\triangle \mathrm{LR}$ is for the improvement in model fit versus the base model. 
TABLE 4: Negative binomial regression models on internationalization

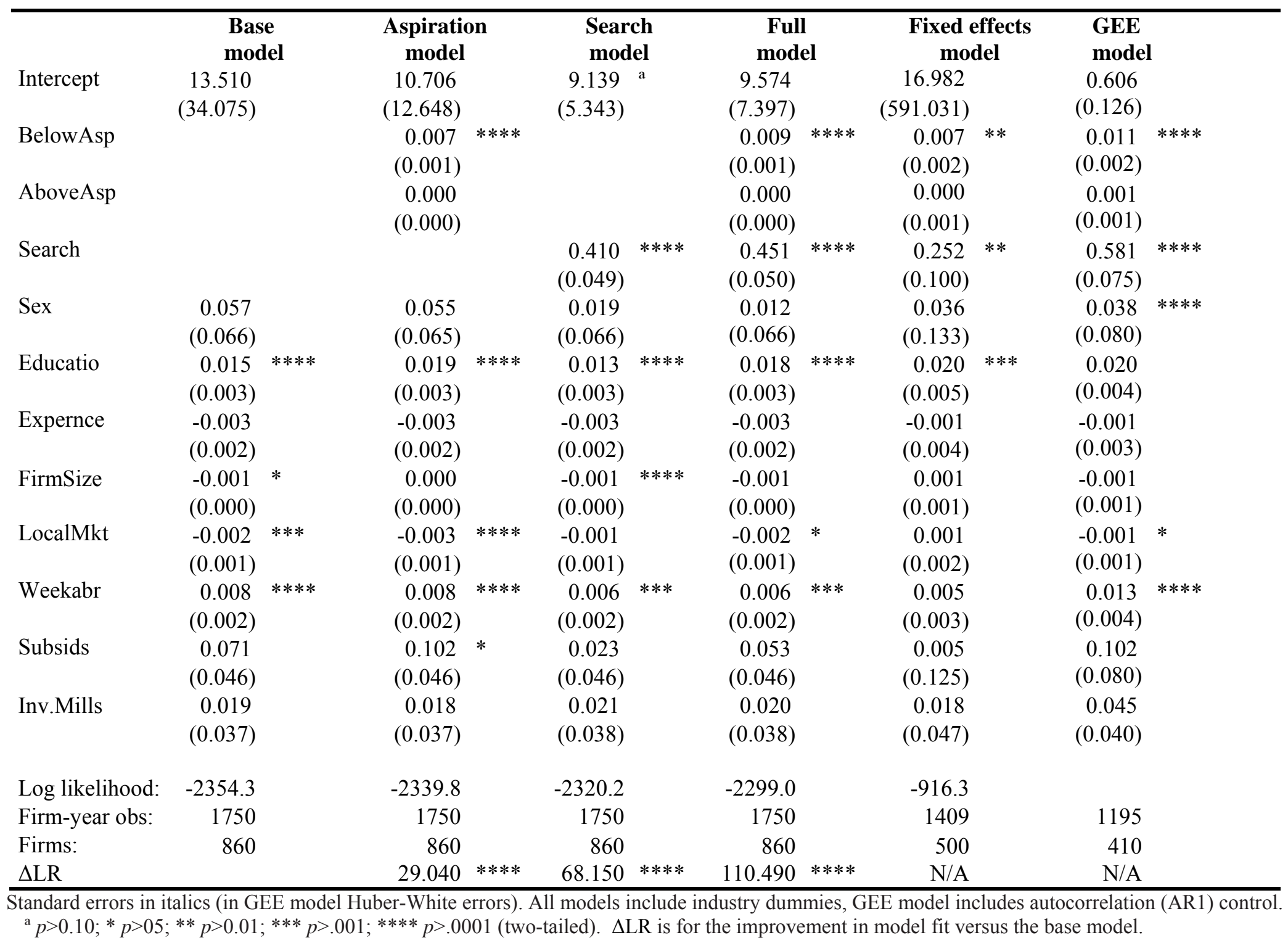




\footnotetext{
${ }^{1}$ Other combinations of performance history and social comparison such as .8 to .2 or .7 to .3 yielded qualitatively similar results.

${ }^{2}$ We also estimated ordered and multinomial probit models with qualitatively identical results, indicating that our findings are robust across model specifications.

${ }^{3} 1$ million krona roughly equals USD120,000
} 


\section{Appendix: Survey questions of new international activities}

Have you initiated any new types of international activities during the past twelve months?

(1) Yes (2) No

If yes, what types of activities?

(1) Started importing from a new country

(2) Started exporting to a new country

(3) Provided license to firm in a new country

(4) Acquired sales license from a firm in a new country

(5) Engaged in financial co-operation agreement (such as joint-venture)

(6) Established sales office overseas

(7) Established production overseas

(8) Started co-operating in other way with domestic partner to expand internationally

(9) Started co-operating in other way foreign partner to expand internationally 